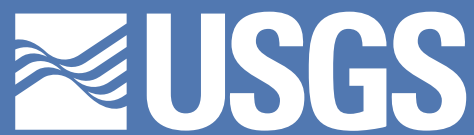

science for a changing world

Prepared in cooperation with the Bureau of Reclamation

\title{
Survival and Growth of Suckers in Mesocosms at Three Locations within Upper Klamath Lake, Oregon, 2018
}

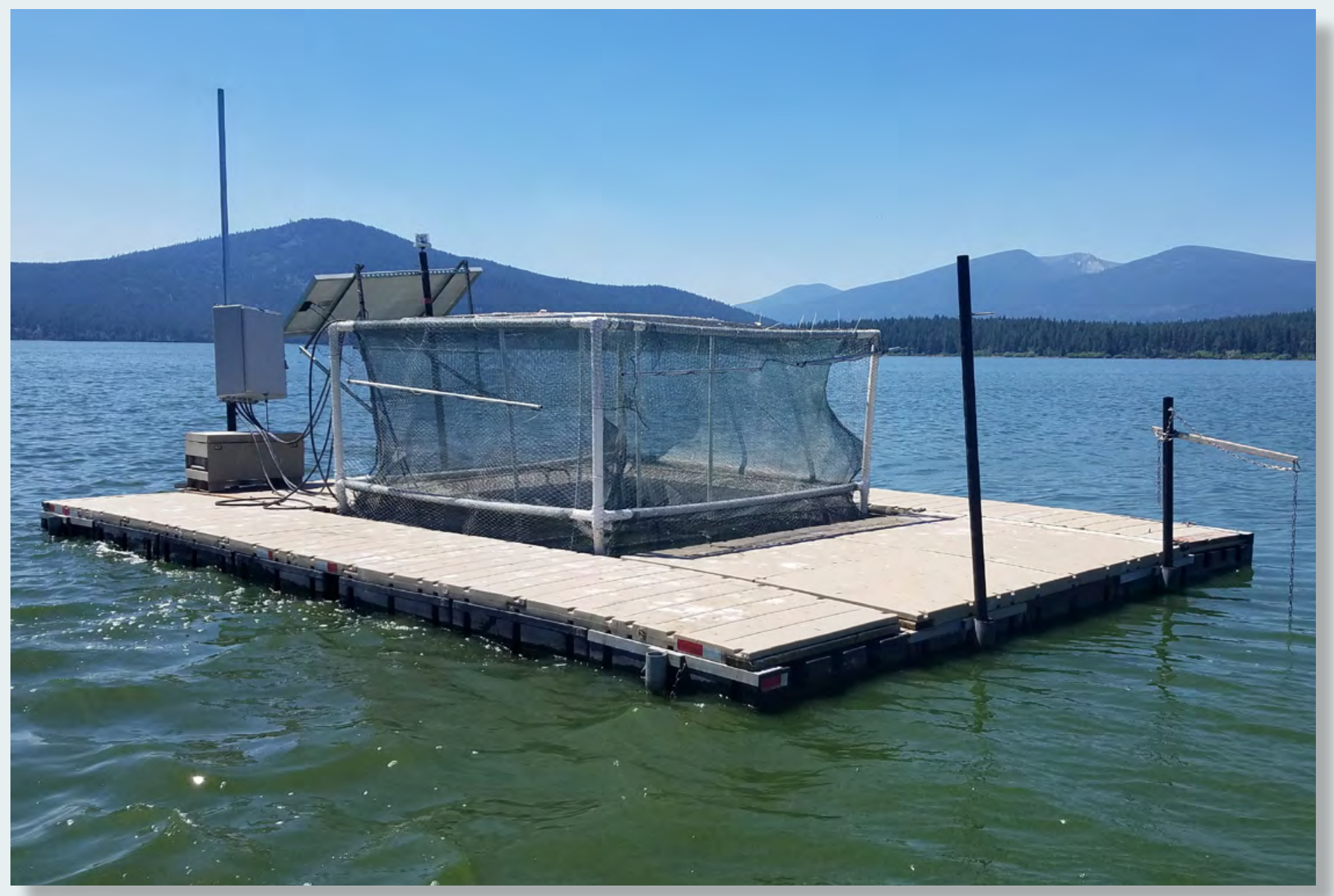

Open-File Report 2021-1036

U.S. Department of the Interior U.S. Geological Survey 
Cover: Mesocosom used to evaluate endangered sucker survival at Shoalwater Bay in Upper Klamath Lake in the summer of 2018. Photograph by Ryan Bart, U.S. Geological Survey. 


\section{Survival and Growth of Suckers in Mesocosms at Three Locations Within Upper Klamath Lake, Oregon, 2018}

By Summer M. Burdick, Carla M. Conway, Carl 0. Ostberg, Ryan J. Bart, and Diane G. Elliott

Prepared in cooperation with the Bureau of Reclamation

Open-File Report 2021-1036 


\section{U.S. Geological Survey, Reston, Virginia: 2021}

For more information on the USGS - the Federal source for science about the Earth, its natural and living resources, natural hazards, and the environment—visit https://www.usgs.gov or call 1-888-ASK-USGS.

For an overview of USGS information products, including maps, imagery, and publications, visit https://store.usgs.gov/.

Any use of trade, firm, or product names is for descriptive purposes only and does not imply endorsement by the U.S. Government.

Although this information product, for the most part, is in the public domain, it also may contain copyrighted materials as noted in the text. Permission to reproduce copyrighted items must be secured from the copyright owner.

Suggested citation:

Burdick, S.M., Conway, C.M., Ostberg, C.O., Bart, R.J., and Elliott, D.G., 2021, Survival and growth of suckers in mesocosms at three locations within Upper Klamath Lake, Oregon, 2018: U.S. Geological Survey Open-File Report 2021-1036, 18 p., https://doi.org/10.3133/ofr20211036.

ISSN 2331-1258 (online) 


\section{Contents}

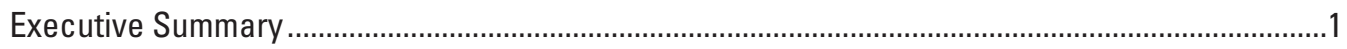

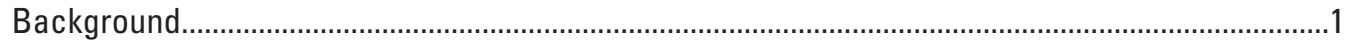

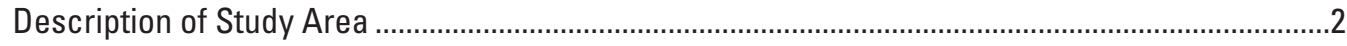

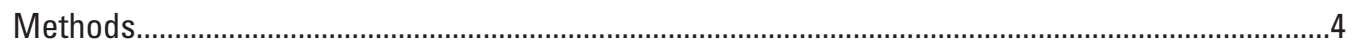

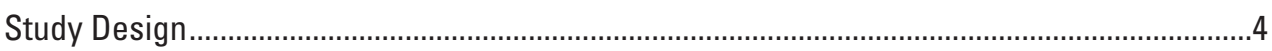

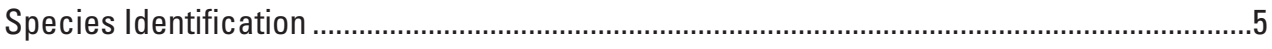

Growth, Ichthyobodo Assessment, and Histology ……......................................................

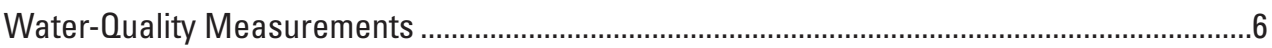

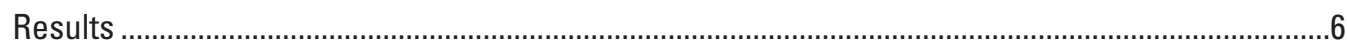

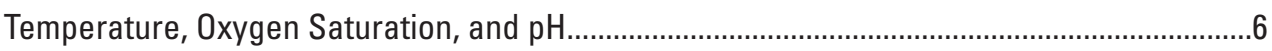

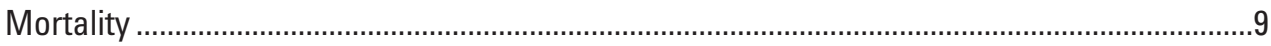

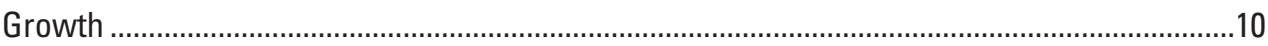

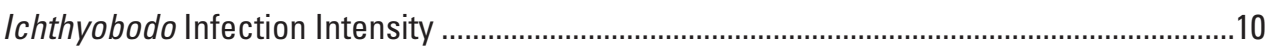

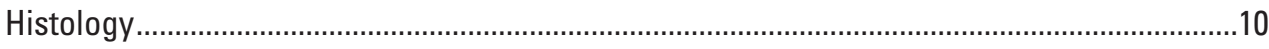

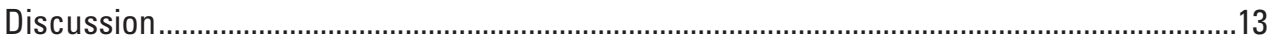

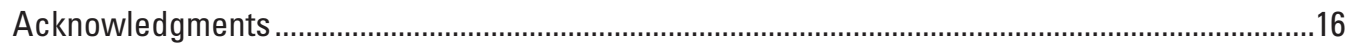

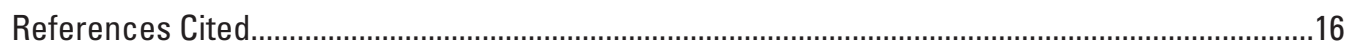

\section{Figures}

1. Map of Upper Klamath Lake, Oregon showing locations of three mesocosms and boat ramps nearest to these mesocosms.

2. Water temperatures in three mesocosms located at Cove Point, Rattlesnake Point, and Shoalwater Bay in Upper Klamath Lake, Oregon, and in a Sucker Assisted Rearing Program pond in 2018

3. Percent oxygen saturation in the three mesocosms located at Cove Point, Rattlesnake Point, and Shoalwater Bay in Upper Klamath Lake, Oregon, in 2018 ...........8

4. Percent oxygen saturation recorded hourly at midwater column depth and the number of hourly mortalities of PIT-tagged juvenile suckers in the Shoalwater Bay mesocosm, in Upper Klamath Lake, Oregon from July 17 to July 19, 2018

5. Percent oxygen saturation recorded hourly at midwater column depth and the number of hourly mortalities of PIT-tagged juvenile suckers in the Shoalwater Bay mesocosm, in Upper Klamath Lake, Oregon from August 10 to August 13, 2018.....10

6. $\mathrm{pH}$ in the three mesocosms located at Cove Point, Rattlesnake Point and Shoalwater Bay in Upper Klamath Lake, Oregon, in 2018

7. Standard lengths of suckers at the time of tagging that survived or died in each of three mesocosms in Upper Klamath Lake, Oregon, in 2018

8. Daily change in length, weight, and condition for SARP-reared suckers maintained in mesocosms at Rattlesnake Point, Cove Point, and in a pond at the SARP rearing facility, plotted against the probability of being a Lost River sucker 


\section{Tables}

1. Latitude, Longitude, and Range of Depths for three mesocosm sites in Upper Klamath Lake, Oregon

2. Number of suckers sacrificed for quantitative polymerase chain reaction and histology.....

3. Numbers of tagged and untagged fish, deaths, recovered bodies, and surviving fish introduced to each mesocosm and the Sucker Assisted Rearing Program control pond.

4. Numbers of suckers that were identified to species, in a pond at the Sucker Assisted Rearing Program rearing facility and in mesocosms at Cove Point and Rattlesnake Point..

5. Number of fish positive by histopathological examination for liver inflammation, hepatocyte vacuolation, and glycogen storage among suckers sampled from the Klamath Tribes Fish Research Facility, Sucker Assisted-Rearing Program control sites, and Upper Klamath Lake mesocosms during the summer and fall of 2018

6. Number of fish positive by histopathological examination for inflammation of the kidney and spleen among suckers sampled from the Klamath Tribes Fish Research Facility, Sucker Assisted-Rearing Program control sites, and Upper Klamath Lake mesocosms during the summer and fall of 2018.

\section{Conversion Factors}

International System of Units to U.S. customary units

\begin{tabular}{|c|c|c|}
\hline Multiply & By & To obtain \\
\hline \multicolumn{3}{|c|}{ Length } \\
\hline millimeter (mm) & 0.03937 & inch (in.) \\
\hline centimeter $(\mathrm{cm})$ & 0.3937 & inch (in.) \\
\hline meter $(\mathrm{m})$ & 3.281 & foot $(\mathrm{ft})$ \\
\hline \multicolumn{3}{|c|}{ Area } \\
\hline square kilometer $\left(\mathrm{km}^{2}\right)$ & 0.3861 & square mile $\left(\mathrm{mi}^{2}\right)$ \\
\hline \multicolumn{3}{|c|}{ Volume } \\
\hline liter $(\mathrm{L})$ & 33.8 & ounce, fluid (fl. oz) \\
\hline \multicolumn{3}{|c|}{ Mass } \\
\hline $\operatorname{gram}(\mathrm{g})$ & 0.03527 & ounce, avoirdupois (oz) \\
\hline
\end{tabular}

Temperature in degrees Celsius $\left({ }^{\circ} \mathrm{C}\right)$ may be converted to degrees Fahrenheit $\left({ }^{\circ} \mathrm{F}\right)$ as follows:

$$
{ }^{\circ} \mathrm{F}=\left(1.8 x^{\circ} \mathrm{C}\right)+32
$$

Concentrations of chemical constituents in water are given in milligrams per liter (mg/L).

\section{Datum}

Horizontal coordinate information is referenced to North American Datum of 1983 (NAD 83). 


\section{Abbreviations and Acronyms}

$\begin{array}{ll}\text { CPT } & \text { Cove Point mesocosm site } \\ \text { DO } & \text { Dissolved oxygen } \\ \text { FBW } & \text { Fish Banks West mesocosm site } \\ \text { K } & \text { Fulton's condition factor } \\ \text { KTFRF } & \text { Klamath Tribes Fish Research Facility } \\ \text { MDN } & \text { Mid North mesocosm site } \\ \text { PAS } & \text { Periodic acid-Schiff } \\ \text { pH } & \text { Negative logarithm of the effective hydrogen ion concentration } \\ \text { PIT } & \text { Passive integrated transponder } \\ \text { prob[LRS } & \text { probability of species assignment as a Lost River sucker } \\ \text { qPCR } & \text { Quantitative polymerase chain reaction } \\ \text { SARP } & \text { Sucker Assisted Rearing Program } \\ \text { RPT } & \text { Rattlesnake Point mesocosm site } \\ \text { SD } & \text { Standard deviation around the mean } \\ \text { SE } & \text { Standard error } \\ \text { SL } & \text { Standard length } \\ \text { SWB } & \text { Shoalwater Bay mesocosm site } \\ \text { TL } & \text { Total length } \\ \text { USGS } & \text { U.S. Geological Survey } \\ \text { USFWS } & \text { U.S. Fish and Wildlife Service }\end{array}$





\title{
Survival and Growth of Suckers in Mesocosms at Three Locations Within Upper Klamath Lake, Oregon, 2018
}

\author{
By Summer M. Burdick, Carla M. Conway, Carl 0. Ostberg, Ryan J. Bart, and Diane G. Elliott
}

\section{Executive Summary}

Due to high mortality in the first year or two of life, Lost River (Deltistes luxatus sp.) and Shortnose suckers (Chasmistes brevirostris sp.) in Upper Klamath Lake, Oregon rarely reach maturity. In 2015, the U.S. Fish and Wildlife Service began the Sucker Assisted Rearing Program (SARP) to improve early life survival before releasing the fish back into Upper Klamath Lake. Survival and growth rates were compared for fish in mesocosms among three potential release or in-lake rearing sites, and in a pond at the SARP rearing facility. Fish used in this study included a mix of Lost River, Shortnose, and Klamath largescale suckers reared at either U.S. Fish and Wildlife Service or Klamath Tribes fish rearing facilities. These sites were Shoalwater Bay (SWB), Rattlesnake Point (RPT), and Cove Point (CPT). Ninety-nine to 103 suckers tagged with passive integrated transponders (PIT) were placed into each mesocosm for up to 80 days and up to 103 days in the SARP pond. Cessation of movement, as determined by passive detection of tagged fish on remote antennas, indicated mortality. Dissolved-oxygen saturation, temperature, and $\mathrm{pH}$ were tracked hourly in each mesocosm. All the suckers placed into the SWB mesocosm died during an extreme hypoxia event. These fish were replaced with another 120 PIT-tagged and 2 untagged hatchery-reared Lost River suckers from the Klamath Tribes Fish Research Facility (KTFRF), of which, all but two died during a second extreme hypoxia event. It was determined that SWB was an unsuitable site for summertime release or rearing of juvenile suckers in 2018. The summer survival rate was $\geq 86$ percent at CPT, RPT, and the SARP pond. Suckers in the SARP pond grew slightly slower and gained less weight relative to increases in length than suckers held at RPT and CPT. All suckers sampled at the start of the study from both the SARP facility and the KTFRF, when water temperatures averaged approximately 18-22 degrees Celsius $\left({ }^{\circ} \mathrm{C}\right)$, were infected with low levels of the gill parasite Ichthyobodo sp. Ichthyobodo sp. was detected on only 1 of 16 suckers sampled from CPT, RPT, and the SARP pond in late September or early October when water temperatures were approximately $16-19{ }^{\circ} \mathrm{C}$, indicating fish were able to shed the parasite in cooler temperatures. Water quality conditions at RPT and CPT were adequate for in-lake rearing of SARP suckers in 2018. Due to interannual differences in water quality conditions, these sites may not be suitable in all years. Future research focused on the suitability of RPT, CPT and other potential sites under in years with varying conditions would be beneficial for improving sucker in-lake rearing practices. Additional research could help to elucidate how size at entry into the mesocosms affects sucker survival.

\section{Background}

Endangered Lost River sucker (Deltistes luxatus sp.) and Shortnose Sucker (Chasmistes brevirostris sp.) populations in Upper Klamath Lake are primarily comprised of senescing adults greater than 25 years of age. Extremely low recruitment to the adult populations is the major bottleneck preventing recovery of these species (Burdick and Martin, 2017; Hewitt and others, 2018). A lack of survival in the juvenile life stage (rather than reproductive failure) prevents recruitment of suckers at around 4 to 7 years of age into adult spawning aggregations. Adult suckers on the other hand typically have high survival (Hewitt and others, 2018). Hypotheses about the causes of juvenile sucker mortality include habitat loss, parasites, pathogens, avian and fish predation, interactions with non-native species, toxic substances from cyanobacteria, or some combination of these factors. Mortality of juvenile suckers in Upper Klamath Lake may also be related to water quality associated with massive blooms and subsequent death of the cyanobacterium Aphanizomenon flos-aquae (Eldridge and others, 2012). During periods of A. flos-aquae blooms, water temperatures average about $21^{\circ} \mathrm{C}$ and $\mathrm{pH}$ can exceed 9.5. Oxygen saturations can decline during periods of A. flos-aquae death, but they rarely decrease below the lowest no-effect level for suckers at long-term monitoring stations throughout the lake (31.3 percent saturation; Meyer and Hansen, 2002; Burdick and others, 2020b). Total ammonia increases during A. flos-aquae death blooms, while $\mathrm{pH}$ declines and un-ionized ammonia remains below the lowest known effect levels of Lost River and Shortnose suckers (0.2 milligrams per liter [mg/L]; Lease and others, 2003). 
To offset juvenile sucker mortality and fulfill the captive propagation program measures outlined in the 2013 Biological Opinion, the U.S. Fish and Wildlife Service (USFWS) began to develop and implement the Sucker Assisted Rearing Program (SARP) for Lost River and Shortnose suckers in 2015 (Day and others, 2017). This program involves capturing larval suckers from the lower Williamson River, treating the fish with salt and formalin to reduce disease and parasites, and rearing the fish until they are ready for release into Upper Klamath Lake. The larvae captured and reared in this program are of mixed species groups and include Lost River, Shortnose and Klamath Largescale suckers. After raising suckers in offsite ponds for 1 or 2 years, the USFWS releases juvenile suckers into Upper Klamath Lake and its tributaries. The objectives of the SARP are to release 8,000-10,000 fish at 172 millimeter (mm) standard length (SL; $200 \mathrm{~mm}$ total length, TL) annually into Upper Klamath Lake (USFWS and NMFS, 2019).

Due to the slow growth of suckers and limited space at the rearing facility, USFWS began moving suckers to net pens near Rattlesnake Point (RPT) in Upper Klamath Lake in June of 2019. The location for these net pens was chosen based on the results of two previous mesocosm studies. In 2016, Hereford and others (2019) observed a gradient of increasing survival and growth of hatchery-reared juvenile Lost River suckers introduced at an average of $102.5 \pm 2.5 \mathrm{~mm} \mathrm{SL}$, among three sites within Upper Klamath Lake (Fish Banks West [FBW], Mid-North [MDN], and RPT; fig. 1). The mortality of hatchery-reared, juvenile Lost River suckers was 83 percent in 2017 compared to only 33 percent in 2016, and lower in both years at RPT than at FBW or MDN (Burdick and others, 2020a). Other than water-quality data collected at four longterm monitoring sites in the lake (fig. 1), there was no information on how suckers might survive at other sites throughout Upper Klamath Lake.

The USFWS began releasing passive integrated transponder (PIT)-tagged and radio-tagged SARP-reared suckers into Upper Klamath Lake in 2017. Due to a very low number of reencounters of PIT-tagged fish and a technical problem with the radio tags, there is almost no information on how well SARP fish survived in the wild. Previous release locations were in the bays and tributaries in the north end of the lake. The three release locations evaluated in this study were chosen based on access to the water at boat ramps and proximity to wetlands. The proximity to wetlands was prioritized based on the perception that they would make high-quality rearing habitat that would increase survival (Cooperman and Markle 2004).

This study examined the survival of SARP-raised suckers in mesocosms within Upper Klamath Lake to help inform decisions on net-pen rearing and fish release locations. This research also provided information on the survival of a mix of three species of SARP suckers within net pens in Upper Klamath Lake. While survival and growth information gained from mesocosm studies may not represent the full ranges of conditions experienced by fish released into the wild, mesocosms offer several convenient advantages for researchers. Mesocosms eliminate the risk of low recapture rates that are possible in studies that depend on capture or redetection of fish. Monitoring PIT-tagged suckers in mesocosms equipped with remote detection equipment and water-quality meters provides daily information on mortality that can be correlated with environmental conditions. The survival at specific locations can be directly assessed because fish are prevented from leaving the study area. Mesocosms allow access to moribund fish so that causes of mortality can be determined with necropsy and histology. While the mesocosms were designed to best simulate conditions in the wild, mesocosms have the potential to alter fish behavior such as the ability to escape poor water quality, alter available prey, and artificially exclude predators.

\section{Description of Study Area}

Upper Klamath Lake is located within the sparsely populated Klamath River basin, in south-central Oregon. At approximately 305 square kilometers $\left(\mathrm{km}^{2}\right)$ it is the largest freshwater lake in Oregon (NRC, 2004). The lake is nearly uniformly shallow, averaging only $2.6 \mathrm{~m}$ deep, except for a 6.4-9.5 m deep trench that parallels the western shore. While most of the lake is devoid of vegetation, there are littoral wetlands along parts of the eastern, northern, and northwest shores. As a result of anthropogenic eutrophication, the phytoplankton community gradually shifted from being dominated by diatoms in the 1910 s to the near monoculture of A. flosaquae that exists today (Bortleson and Fretwell, 1993). The bloom and subsequent death of $A$. flos-aquae drive waterquality dynamics in the lake. 


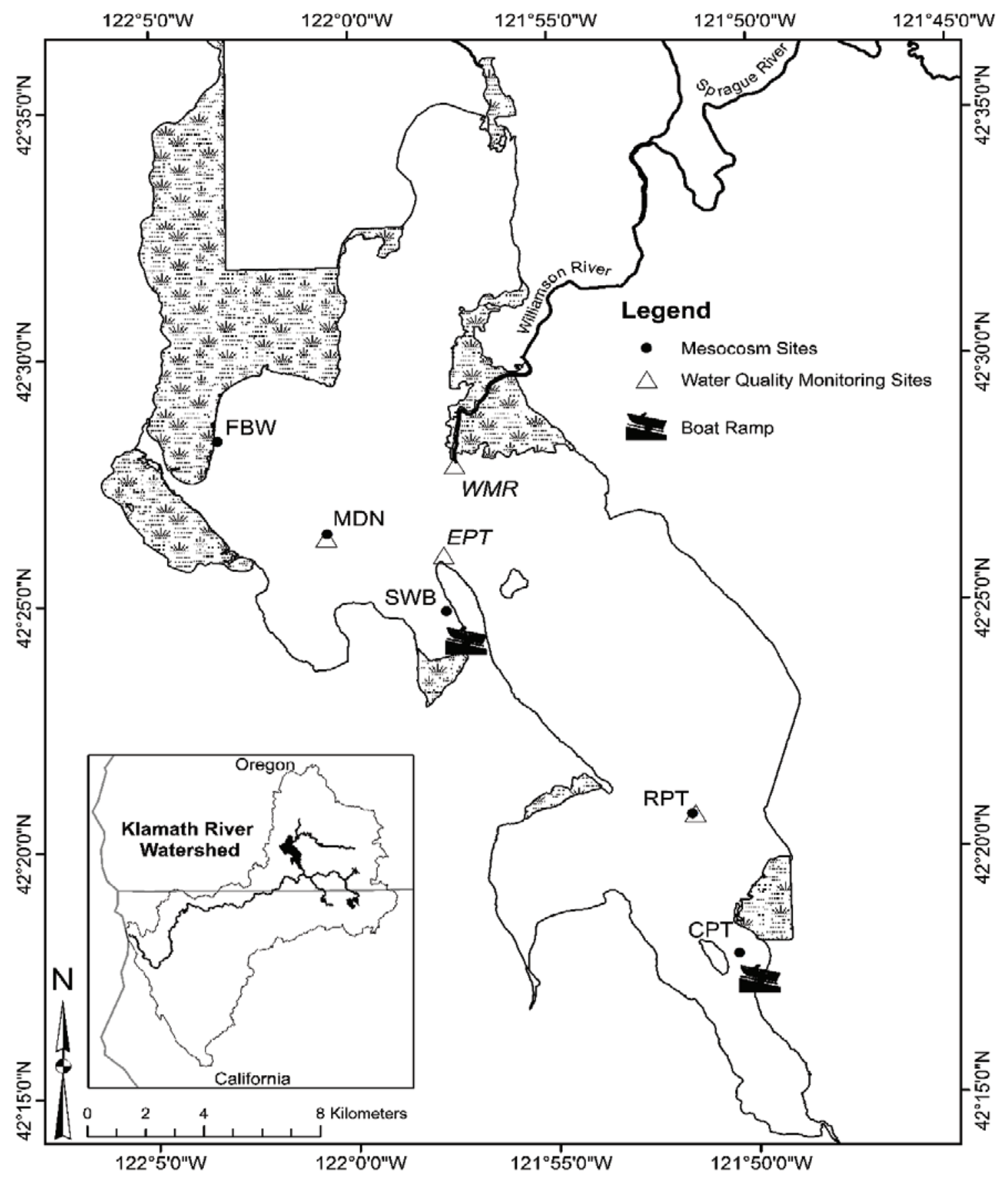

Figure 1. Map of Upper Klamath Lake, Oregon showing locations of three mesocosms and boat ramps nearest to these mesocosms. The locations of mesocosms in previous studies and long-term water-quality monitoring stations are also shown. Fish Banks West, FBW; Mid-North, MDN; Williamson River Mouth, WMR; Eagle Point, EPT; Shoalwater Bay; SWB; Rattlesnake Point, RPT; and Cove Point, CPT. 


\section{Methods}

\section{Study Design}

In this study single mesocosms were established at Shoalwater Bay (SWB), Cove Point (CPT), and RPT in Upper Klamath Lake, Oregon, in June of 2018 (fig. 1; table 1). At the time that these sites were selected, they were being considered for net pen rearing, SARP release locations, or both (E. Childress, oral commun., 2017, USFWS). SWB had a boat ramp that provided easy access and was used as a release site in April of 2017. There is a large wetland in Shoalwater Bay that USFWS predicted would provide good habitat and high survival. The RPT site was selected due to relatively good success rearing suckers in a mesocosm at this site in previous years (Hereford and others, 2019; Burdick and others, 2020a). RPT is offshore and not easily accessible from a boat ramp. CPT, which is near a private boat ramp, was selected for its proximity to RPT and easy access. CPT was also located close to Hanks Marsh, which USFWS predicted would provide good habitat for age-1 or age-2 SARP suckers, despite being poor habitat for larval and age-0 suckers (Anderson and others, 2009).

The mesocosms were approximately 3 square meters $\left(\mathrm{m}^{2}\right)$ enclosures that extended the depth of the entire water column. The enclosures were sitting on the bottom and allowed suckers access to prey in the benthos. The mesocosms were constructed of 0.62 centimeters squared $\left(\mathrm{cm}^{2}\right)$ nylon netting stretched across ridged polyvinyl chloride (PVC) pipe frames. Mammalian predation was prevented by wrapping vertical sides with $2.54 \mathrm{~cm}^{2}$ poultry wire. Bird predation was prevented by covering the top of the mesocosm with $2.5 \mathrm{~cm}^{2}$ nylon bird netting. In each mesocosm, three antennas $(1.2 \times 0.6$ m) detected PIT-tagged sucker movements near the surface, at mid-water column, and on the bottom. The surface antenna floated and its vertical position declined over the study as the lake surface dropped. Two additional small $(0.3 \times 0.3 \mathrm{~m})$ antennas were placed in opposite corners at the bottom of each mesocosm, to increase detection of benthic movements.

Fish detections were recorded with Biomark ${ }^{\circledR}$ MTS systems (master controller and IS1001 ${ }^{\mathrm{TM}}$ nodes). Master controllers were programmed to record no more than one detection per unique tag per antenna every 10 minutes, unless the tag was detected at a second antenna. This prevented overloading the data capacity of the system. A tag detected at two or more

Table 1. Latitude, Longitude, and Range of Depths for three mesocosm sites in Upper Klamath Lake, Oregon.

\begin{tabular}{lccc}
\hline \multicolumn{1}{c}{ Site } & Latitude & Longitude & Depth Range (m) \\
\hline Shoalwater Bay & 42.41419 & -121.9614 & $2.2-2.9$ \\
Rattlesnake Point & 42.34489 & -121.8589 & $2.0-2.8$ \\
Cove Point & 42.29750 & -121.8411 & $1.2-2.0$ \\
\hline
\end{tabular}

antennas within 10 minutes would reset the record delay for that tag, which resulted in more frequent detection of fish that moved rapidly among antennas.

Two batches of suckers were tagged for this study. SARP-reared suckers were raised from wild-caught larvae collected from the lower Williamson River in the spring of 2017. SARP suckers were initially reared in tanks and then moved to earthen ponds to grow. Lost River suckers were propagated from wild, shoreline spawning Lost River suckers captured from Upper Klamath Lake in 2015. The eggs were hatched at the Coleman Fish Hatchery (Anderson, California). These fish were transferred as larvae to the KTFRF in November of 2015 (hereafter referred to as KTFRF suckers). Both groups of suckers were reared on a diet of Otohime (Reed Mariculture, Campbell, California) before being used in our study.

A mixed species group of suckers from the SARP and Lost River suckers from KTFRF were selected for tagging. A total of 411 age-1 or age-2 SARP suckers were tagged on June 28, 2018 (Trial 1) and 140 age-2 KTFRF suckers were tagged on July 26, 2018 (Trial 2). A total of 17 suckers tagged at KTFRF died within 11 days of tagging and one more died in transport to cages. SARP fish were weighed and measured just prior to tagging and KTFRF fish were measured but not weighed on July 31,2018 . SARP suckers were randomly assigned to each of three mesocosms and a control pond in order to achieve a similar size distribution among groups. SARP suckers averaged ( \pm standard deviation [SD]) $106 \pm 11$ $\mathrm{mm} \mathrm{SL}$ and $19 \pm 7 \mathrm{~g}$, whereas KTFRF suckers averaged $156 \pm 41 \mathrm{~mm}$ SL. Suckers were sedated with tricaine mesylate (MS-222) and PIT-tagged using Biomark ${ }^{\circledR}$ MK25 implant guns and $12 \mathrm{~mm}, 134.2 \mathrm{kHz}$, full duplex PIT tags in preloaded needles. Tags were implanted along the ventral surface in an anterior to posterior direction to keep the needle and tag away from sensitive organs such as the heart (Burdick, 2011). After tagging, suckers were monitored in indoor tanks daily for tag loss and mortality until they were ready to move to mesocosms or an outdoor SARP pond.

Suckers were transported in coolers equipped with aerators to three mesocosm sites. On July 9103 (CPT), 100 (RPT), and 99 (SWB) PIT-tagged suckers were introduced into each mesocosm and 100 were moved to a SARP pond to be used as a control group. After a total mortality event at the SWB site, the mesocosm was restocked with $122 \mathrm{KTFRF}$ suckers on August 6, 2018. All KTFRF fish were checked for PIT tags several days prior to stocking, but 2 fish were never detected in the mesocosm and later accounted for as part of the untagged mortalities. This suggests these two fish lost tags prior to being placed into the mesocosm. To acclimate fish to lake conditions, lake water was slowly mixed with water in the coolers over a period of 45-60 minutes. To ensure that our assessment of survival was unbiased by potential transportrelated stress, suckers were allowed to acclimate to lake conditions for 7 days before data collection on their activity began. 
Fish at the SARP facility were moved to an earthen lined pond after tagging. Ponds were protected from avian and mammalian predation with bird netting. Fish were fed a diet of Otohime S2 according to the protocols established by the USFWS fish care staff. Ponds did not have PIT antenna equipment to check for movement or mortality. Instead, ponds were checked five days per week for dead fish floating on the surface.

Mesocosms were checked for dead or moribund suckers Monday through Friday in July, August, and September and once per week in October 2018. Dead suckers and a moribund sucker were removed from mesocosms, measured, and scanned for a PIT tag. Dead or moribund suckers were not replaced at CPT and RPT in order to prevent possible introductions of new parasites or disease.

The timing of mortality in mesocosms for each fish was inferred from a lack of movement determined by detections among antennas. The timing of collection of dead fish that retained their tags was used to corroborate death dates when possible. The single moribund sucker recovered during this study was assigned a death date on the day it was removed from the mesocosm. The precision with which the timing of death could be identified depended on the movement patterns at end-of-life. In some cases, the hour that a fish stopped moving could be determined and in others only the day of death could be determined. We presumed the cessation of movement indicated death, but in some cases the fish may have been moribund for some time before death.

\section{Species Identification}

Fish from the SARP facility consisted of an undetermined combination of Lost River, Shortnose, and Klamath largescale suckers (Catostomus snyderi). Due to budget constraints, the species of most (but not all) of the fish in our study were identified using genetics (Hoy and Ostberg, 2015). Suckers species in the SARP $(n=95)$, CPT $(n=85)$, and RPT $(n=84)$ groups were identified. Suckers that died in the SWB mesocosm were not identified to species. Genetic samples from all other fish used in the study were archived for potential future analysis.

Genetic analyses were conducted on an approximately $2 \mathrm{~mm}^{2}$ tissue sample collected from the upper caudal fin and then analyzed using methods described by Hoy and Ostberg (2015). A total of 18 nuclear DNA TaqMan ${ }^{\circledR}$ assays were used to differentiate the species based on single nucleotide polymorphisms (Hoy and Ostberg, 2015). Program STRUCTURE and two population clusters were used to calculate a posterior probability of taxon assignment. Two clusters, rather than three, were used because primers were not available to distinguish all three species at the time of our analysis. Our method allowed us to estimate a probability of a SARP sucker being a Lost River sucker. When categorization to the taxon level was appropriate for analysis, suckers were categorized with a probability of $\geq 0.95$ of correct assignment as a Lost River sucker. Fish with a $\leq 0.05$ probability of being a Lost River sucker were called Shortnose or Klamath largescale sucker (SNS-KLS). The term "intermediate prob[LRS]" was used for fish with probabilities of species assignment between 0.05 and $0.95(0.05 \leq$ intermediate prob $[\mathrm{LRS}] \leq 0.95)$.

\section{Growth, Ichthyobodo Assessment, and Histology}

To compare the growth, condition, and health between fish reared in the three mesocosms and SARP pond, surviving suckers were collected at the end of the study. Fish that survived to the study completion were collected from mesocosms on September 26 and 27, 2018 and fish from the SARP pond were harvested on October 3, 2018. Surviving suckers were weighed, measured, and inspected for external afflictions. The average daily changes in length, weight, and condition factor from tagging until study completion were compared. Fulton's condition factor was calculated as $K=\left(\right.$ weight $\left./ \mathrm{SL}^{3}\right) \times 10^{5}$ (Ricker, 1975). Plots were created to show the daily change in each growth metric by the probability of being a Lost River sucker for all fish in the RPT and CPT mesocosms and in the SARP pond where genetic information was available. Growth was not assessed for the fish in the SWB mesocosm because the fish died early in the experiment.

To assess health and potential causes of mortality, juvenile suckers were sacrificed for histology and quantitative polymerase chain reaction (qPCR) analysis to determine the presence and intensity of Ichthyobodo sp. Ichthyobodo sp. was the focus in this study because Hereford and others (2019) previously noted high abundance of this parasite on moribund juvenile Lost River Suckers in mesocosms in Upper Klamath Lake. A subsample of fish weas sacrificed from the SARP rearing facility and the KTFRF prior to introducing the remaining fish to the lake or control pond to obtain baseline information (table 2). Only one moribund fish was captured on July 12, 2018 and sampled to get information on the cause of death. Fish were also collected at the end of the experiment from all three mesocosms and the control pond to determine the health and condition of survivors.

The fish were sacrificed by an overdose of MS222. A sample of gill tissue was collected and preserved in 95 percent ethanol for qPCR analysis. The fish were opened along the ventral surface. The color and condition of organs were noted as tissues were loosened and the intestine was sliced to facilitate penetration of the preservative. The fish were preserved in 10 percent phosphate buffered formalin and transferred to ethanol after 72 hours of preservation.

Samples of gill, liver, spleen, kidney, heart, pancreas and gastrointestinal tract were collected from formalin-preserved suckers for histopathological analysis. Skin and skeletal muscle also were dissected from fish with external lesions or parasites. All tissues were processed and embedded in paraffin according to conventional procedures, sectioned at 5 microns and stained with Gill's No. 3 hematoxylin and eosin (Thermo Scientific, Waltham, Massachusetts), according to the manufacturer's instructions. The degree of host response, 
Table 2. Number of suckers sacrificed for quantitative polymerase chain reaction (qPCR) and histology.

[Number of suckers sacrificed (n), location, date in 2018, type of sample collected, and sample timing within the study are given. Fish were sacrificed from the Sucker Assisted Rearing Pond rearing facility (SARP), the Klamath Tribes Fish Research Facility (KTFRF), Cove Point mesocosm (CPT), Rattlesnake Point mesocosm (RPT), and the Shoalwater Bay mesocosm (SWB).]

\begin{tabular}{llrll}
\hline \multicolumn{1}{c}{ Location } & \multicolumn{1}{c}{ Date(s) } & n & \multicolumn{1}{c}{ Type of sample } & \multicolumn{1}{c}{ Sample timing } \\
\hline SARP & June 28 & 10 & qPCR & Start of study \\
SARP & June 29 & 1 & Histology (moribund) & Start of study \\
SARP & July 9 & 5 & Histology & Start of study \\
KTFRF & July 26 & 5 & Histology and qPCR & Start of study \\
RPT & July 12 & 1 & Histology and qPCR (moribund) & Mid study \\
SWB & September 28 & 2 & Histology and qPCR & End of study \\
CPT & September 27 & 10 & Histology and qPCR & End of study \\
RPT & September 26 & 10 & Histology and qPCR & End of study \\
SARP & October 3 & 5 & Histology and qPCR & End of study \\
\hline
\end{tabular}

including distribution and severity of inflammation, fibrosis, and cell necrosis per $200 \times$ microscope field, was scored using a four-point scale (0-3). Host response distribution was ranked as none, focal, multifocal, or diffuse, and severity was scored as none, mild, moderate, or severe. The amount of liver energy storage (as hepatocyte glycogen) was used as an index of relative nutritional status and was assessed by the presence and appearance of vacuoles in hepatocyte cytoplasm, and the staining characteristics of the cytoplasm. Periodic acid-Schiff (PAS) and PAS-diastase (Carson, 1997) were used to stain liver tissue and estimates of the amount of glycogen stored in the hepatocyte cytoplasm were rated as none, low or high. Parasites were identified and the degree of host response was assessed.

Gill tissue collected for qPCR was weighed prior to being assayed by qPCR. Extraction of DNA was completed using Qiagen DNeasy ${ }^{\circledR}$ Blood and Tissue Kits following the manufacturer's protocol. DNA was stored at $-20{ }^{\circ} \mathrm{C}$ prior to analysis. A subsample of extracted DNA was assayed for the gill parasite Ichthyobodo sp. by qPCR methods described by Isaksen and others (2012) using the $\mathrm{ViiA}^{\mathrm{TM}} 7$ real-time PCR system (Thermo Fisher Scientific, Waltham, Massachusetts). The reactions contained 6 microliters $(\mu \mathrm{L})$ of real-time PCR master mix (TaqMan ${ }^{\circledR}$ Gene Expression Master Mix; Life Technologies, Carlsbad, California), 900 nanomolar (nM) of each primer, $200 \mathrm{nM}$ of the probe, and $5 \mu \mathrm{L}$ of DNA template in a total reaction volume of $12 \mu \mathrm{L}$. Quantification of target DNA was achieved using a standard curve generated from a plasmid-based artificial positive control. The artificial positive control encodes the qPCR target amplicon plus an artificial tag sequence (Integrated DNA Technologies ${ }^{\mathrm{TM}}$, Coralville, Iowa). The amount of total DNA added to each qPCR reaction was normalized to 100 nanograms, and cycle threshold values were converted to copies of Ichthyobodo sp. DNA per milligram (mg) of tissue (Isaksen and others, 2012).

\section{Water-Quality Measurements}

Hourly water temperature, dissolved oxygen (DO) concentration, $\mathrm{pH}$, and conductivity were recorded by a YSI ${ }^{\circledR}$ EXO sonde (YSI, Yellow Springs, Ohio) with an optical DO probe within each mesocosm. Sondes were deployed at midwater column depth on July 6 at SWB and July 16 at the other two mesocosms. Field sondes were retrieved, cleaned, and replaced regularly with a laboratory-calibrated replacement sondes according to U.S. Geological Survey protocol (Wagner and others, 2000). Sondes were retrieved from September 14 to 17 at all three mesocosm sites. Temperature was recorded hourly at the bottom of the SARP pond. No other waterquality data were collected from the SARP ponds.

The percent oxygen saturation was calculated from DO concentration and temperature data, using the Benson and Krause equations and by applying an altitude correction (Benson and Krause, 1980 and 1984; Rounds, 2011). Percent oxygen saturation was used in our models, because it is a more direct measure of oxygen availability for fish than DO concentration.

\section{Results}

\section{Temperature, Oxygen Saturation, and pH}

Mean daily water temperatures were similar among mesocosms and in the SARP pond for most of the study, but diel range in temperatures varied (fig. 2). Water temperature in the SARP pond had greater diel variation and was, on average, cooler during August and warmer in early September than in the mesocosms. Mean daily water temperatures were the warmest at all three mesocosms and in the SARP pond from July 16 to 31,2018 . Minimum temperatures during the second half of July were $21.2{ }^{\circ} \mathrm{C}$ in the mesocosms and 18.8 
${ }^{\circ} \mathrm{C}$ in the SARP pond. Maximum daily temperatures during July were similar among mesocosms and the SARP pond and averaged approximately $25^{\circ} \mathrm{C}$. Mesocosms and the SARP pond cooled by about $3{ }^{\circ} \mathrm{C}$ during the first few days of August and then warmed to an average of approximately $22^{\circ} \mathrm{C}$ by August 10. This was followed by a cooling trend until the end of the season in all mesocosms when temperatures averaged approximately $15^{\circ} \mathrm{C}$. The SARP pond generally cooled down until August 27 when mean daily temperature was approximately $17^{\circ} \mathrm{C}$. The SARP pond temperatures were upwardly adjusted by hatchery staff by increasing the input of geothermally heated water, beginning at the end of August to maintain a mean daily temperature of approximately $18^{\circ} \mathrm{C}$.
Mean daily oxygen saturation at CPT and RPT was around 100 percent for most of the study period with a few exceptions (fig. 3). The minimum percent oxygen saturation recorded at CPT was 42.9 percent, which is above the lowest no-effect threshold for juvenile Lost River or Shortnose suckers of 31.3 percent (Meyer and Hansen, 2002; Burdick and others, 2020b). Oxygen saturation dropped to between 40 and 53 percent at RPT on July 16 and 18 and on August 14. From 0200 to 1100 on July 17 oxygen saturation ranged from 18.7 to 31.1 percent at RPT and included 3 hours below 24-hour median lethal level for juvenile Lost River suckers (20.7 percent; Saiki and others, 1999).

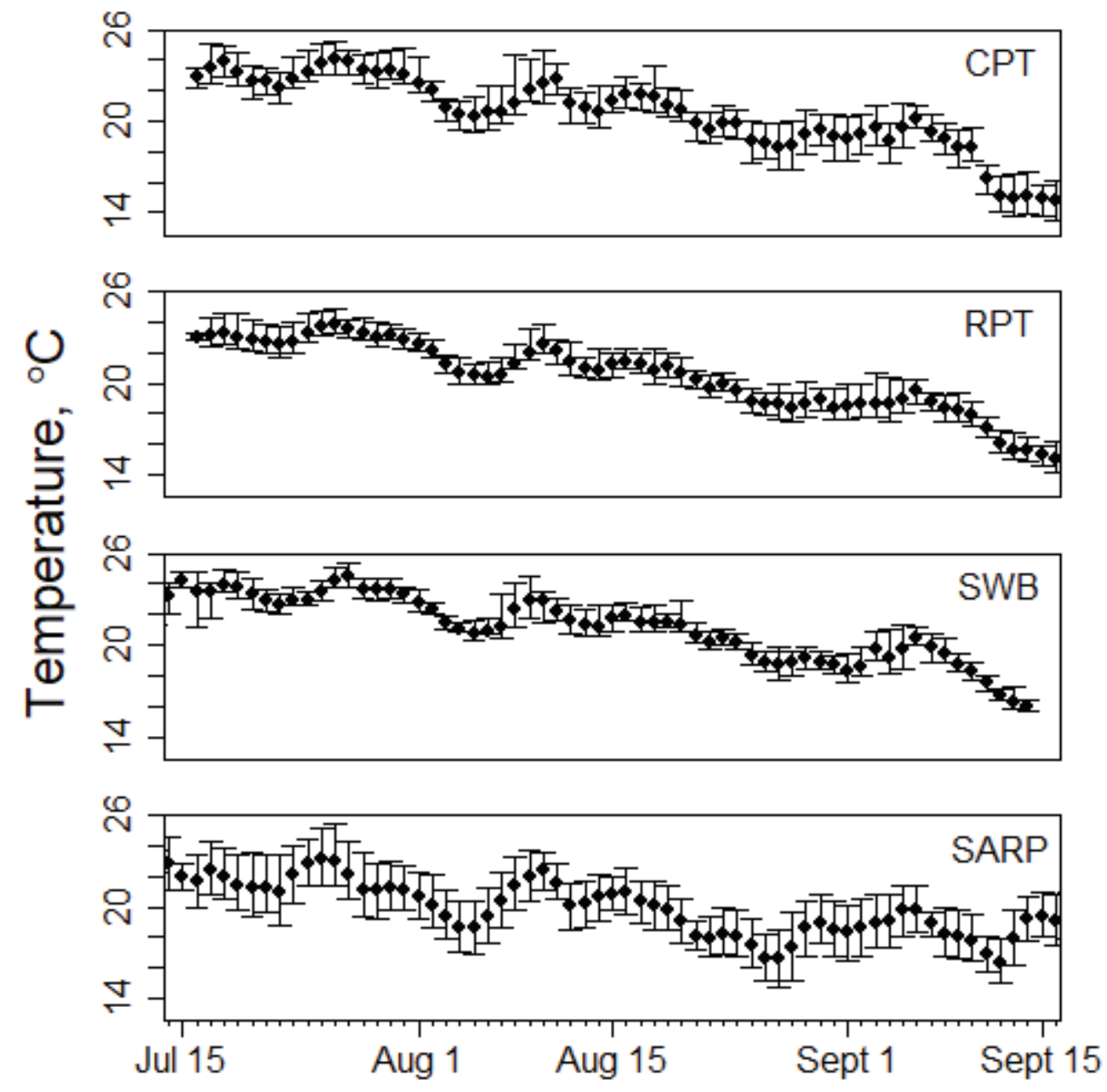

Figure 2. Water temperatures in three mesocosms located at Cove Point (CPT), Rattlesnake Point (RPT), and Shoalwater Bay (SWB) in Upper Klamath Lake, Oregon, and in a Sucker Assisted Rearing Program (SARP) pond in 2018. Daily mean water temperatures are indicated by a dot and whiskers indicate daily minimum $(\mathrm{min})$ and maximum $(\mathrm{max})$ temperatures. 


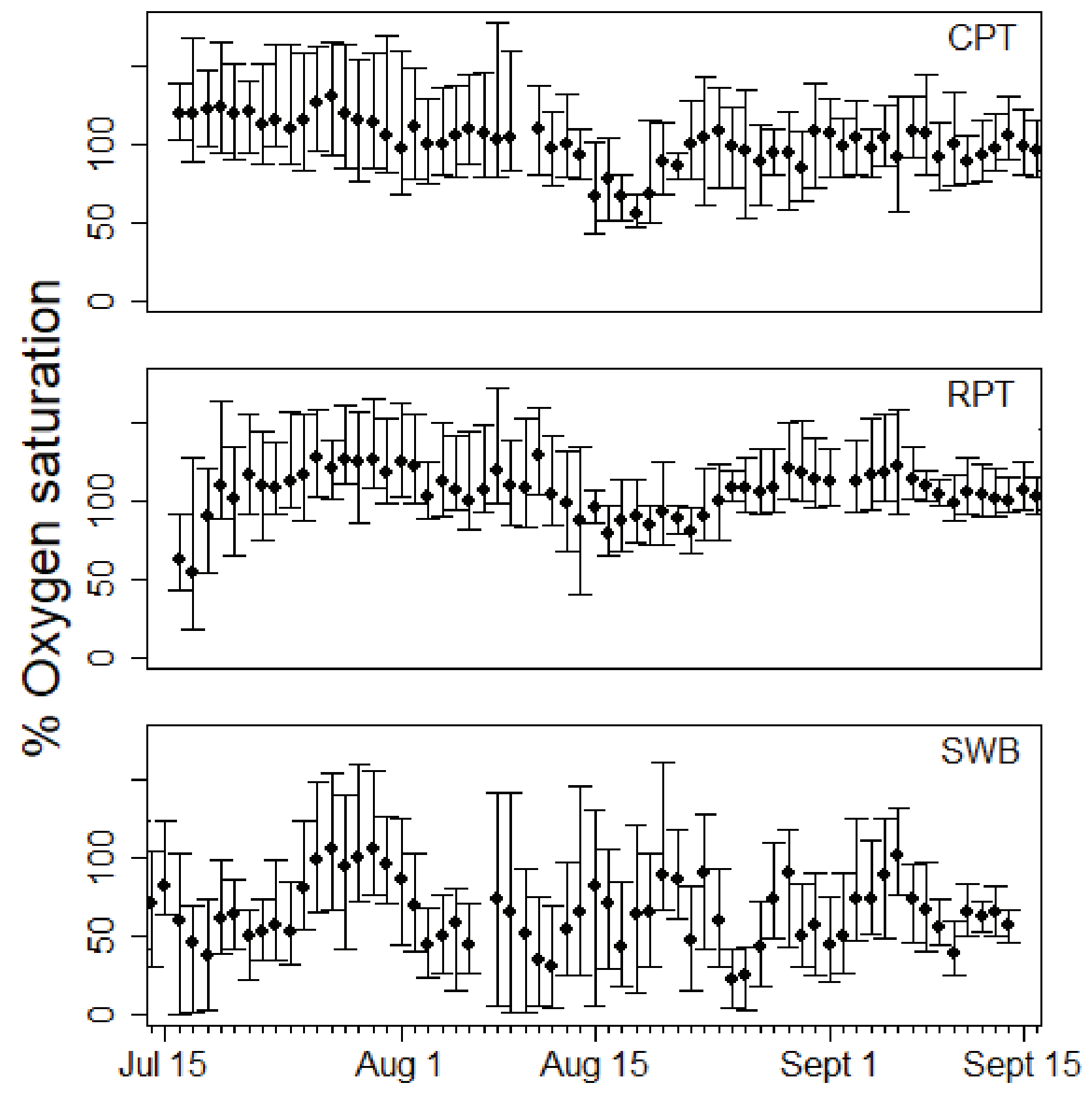

Figure 3. Percent oxygen saturation in the three mesocosms located at Cove Point (CPT), Rattlesnake Point (RPT), and Shoalwater Bay (SWB) in Upper Klamath Lake, Oregon, in 2018. Daily mean percent (\%) oxygen saturations are indicated by a dot and whiskers indicate daily min and max percent oxygen saturation. 
In contrast to CPT and RPT, mean daily percent oxygen saturation at SWB only exceeded 100 percent on four days. Oxygen saturation was less than 31.1 percent for 187 total hours and less than 20.7 percent for 83 total hours over the study period. Oxygen saturation was also less than the acutely lethal level of 13.3 percent for a total of 52 hours at SWB. An extreme hypoxia event occurred on July 18, when oxygen saturation declined from 21.6 percent at 0400 to 2.9 percent at 0700 (fig. 4). Oxygen saturation declined below 13.1 percent on August 10 for a total of three hours. The longest period of extreme hypoxia occurred at SWB on the night of August 11 and 12 , when oxygen saturation declined to less than 13.3 percent for 11 consecutive hours (fig. 5). Two other extreme hypoxia events occurred on August 25 from 0200 to 1400 and on August 26 from 0200 to 1000 . Oxygen saturation was below 24.5 percent during these two events, with minimum oxygen saturation reaching 5.1 percent on August 25 and 3.5 percent on August 26.

From July 15 to August 14, pH ranged from 8.7 to 10.0 at CPT and 8.4 to 9.8 at RPT, and daily mean $\mathrm{pH}$ was $>9$ at both sites (fig. 6). From July 15 to August 12, pH at SWB ranged from 8.0 to 9.8 and daily mean $\mathrm{pH}$ was $\geq 8.8$. The $\mathrm{pH}$ declined at CPT from August 15 until the seasonal minimum mean daily $\mathrm{pH}$ of 8.3 was reached on August 18. The $\mathrm{pH}$ declined at RPT from August 15 until the seasonal minimum mean daily $\mathrm{pH}$ of 8.2 was reached on August 22. A period of lower $\mathrm{pH}$ occurred at SWB from August 24 to 26 when mean daily pH was around 7.8 (fig. 6).

\section{Mortality}

Most of the suckers in CPT, RPT, and the SARP pond survived to the end of the study (table 3), whereas all suckers introduced on July 9 to SWB died between 0400 and 0700 on July 18 during a low oxygen event. All but 6 of the 120 tagged KTFRF Lost River suckers, introduced to SWB on August 6, died between 1100 on August 10 and 0100 on August 14, when oxygen saturation was low (fig. 5). Most of these deaths occurred from 0800 to 1600 on August 12 when oxygen saturation was $<13.1$ percent. Three fish died at SWB during a 3 -hour period on August 10 when oxygen saturation was less than 13.1 percent for 3 consecutive hours. One fish died on August 17 and another fish died on September 11. Two large ( $>140 \mathrm{~mm} \mathrm{SL}$ ) Lost River suckers survived to the end of the study at SWB (fig. 7).

A total of 15 fish died at CPT: 8 died from July 10 to 13, 3 died from August 13 to 15, and 4 died from August 30 to September 4. A total of 9 fish died at RPT: 5 from July 11 to July 14, and one each on August 11, September 6, September 11, and September 22. None of these deaths were obviously associated with extreme water-quality events. Fish that died were of a similar initial length as fish that survived in CPT and RPT (fig. 7). Approximately equal proportions of suckers in each taxon survived at CPT, RPT, and in the control group in the SARP pond (table 4).

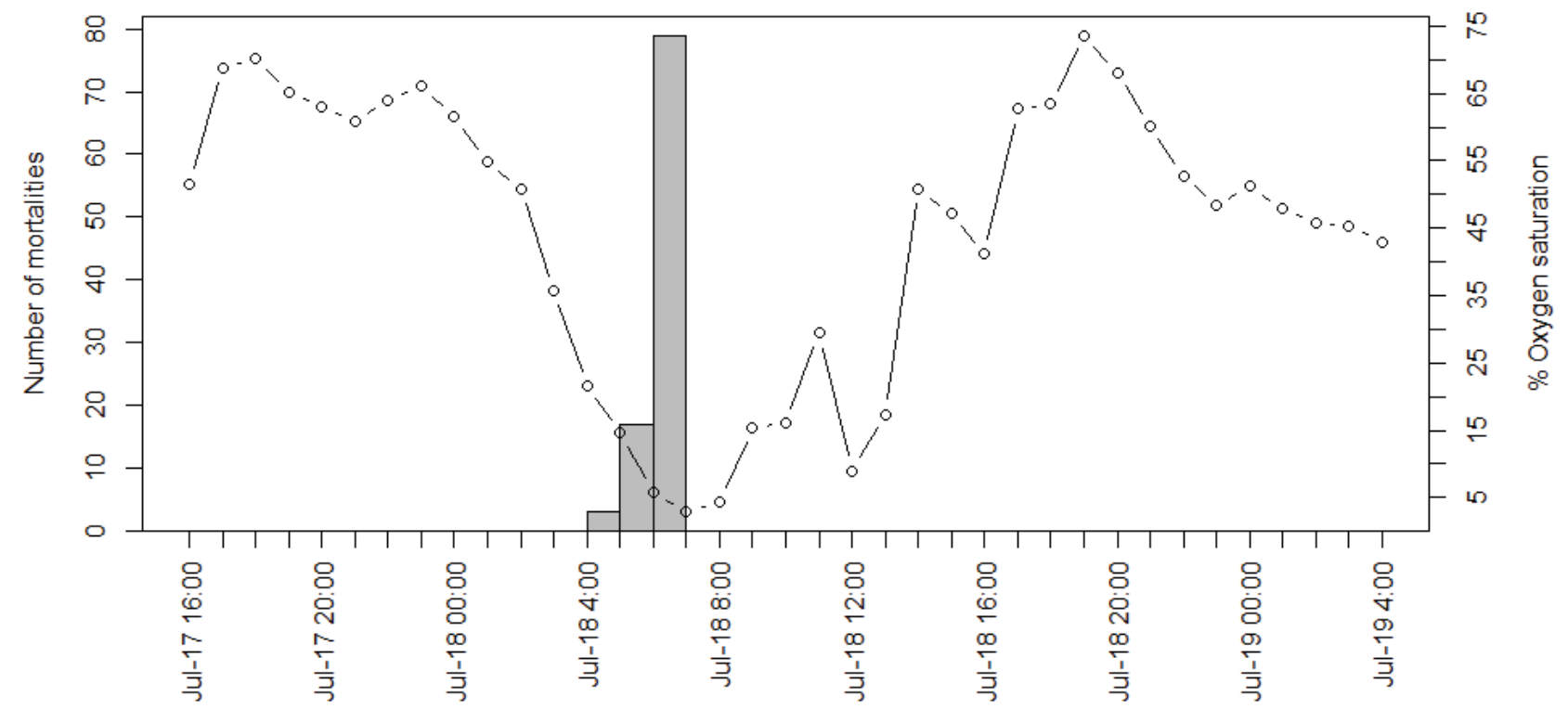

Figure 4. Percent (\%) oxygen saturation recorded hourly at midwater column depth (open circles) and the number of hourly mortalities of PIT-tagged juvenile suckers (grey bars) in the Shoalwater Bay mesocosm, in Upper Klamath Lake, Oregon from July 17 to July 19, 2018. 


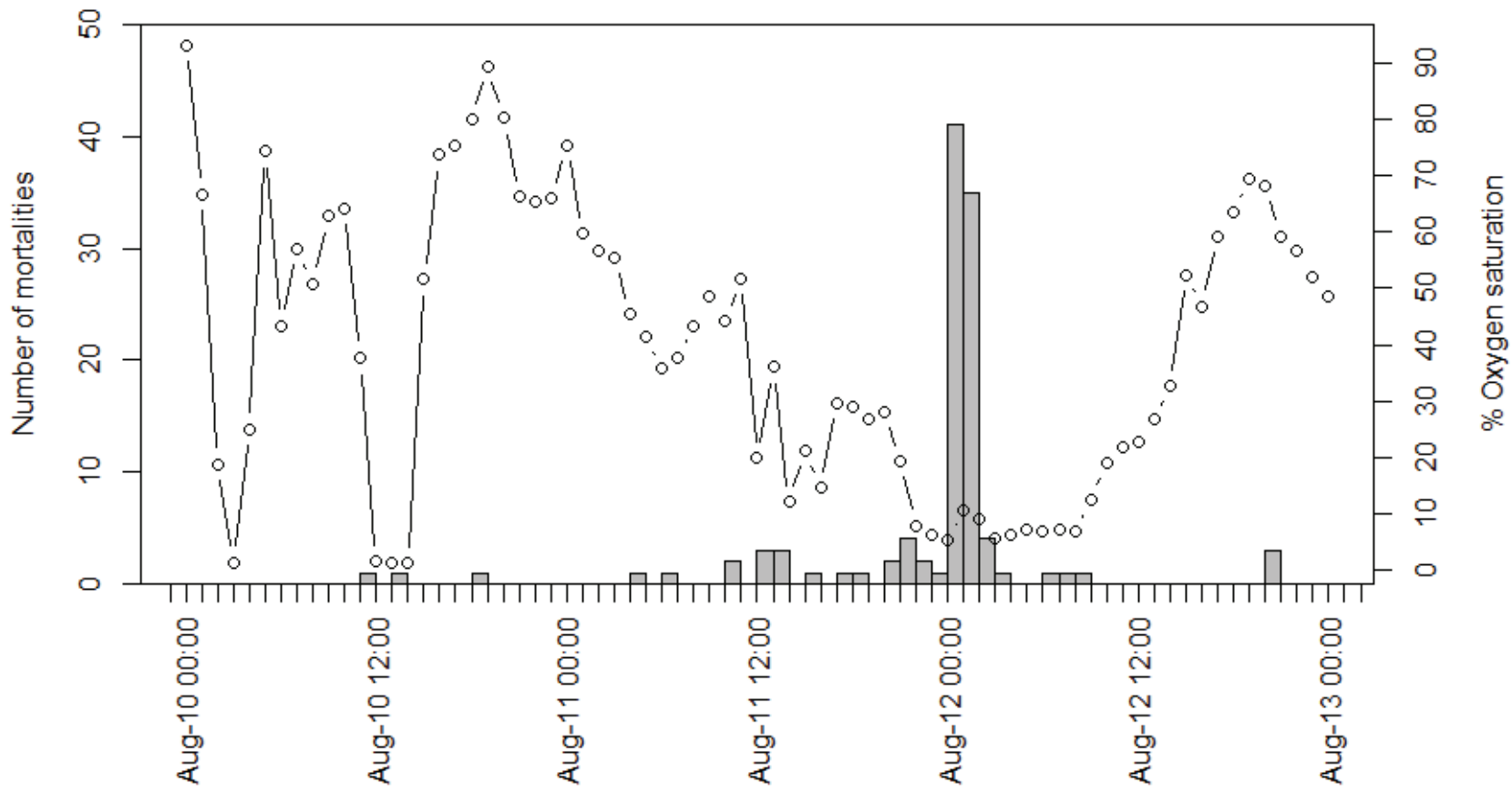

Figure 5. Percent (\%) oxygen saturation recorded hourly at midwater column depth (open circles) and the number of hourly mortalities of PIT-tagged juvenile suckers (grey bars) in the Shoalwater Bay mesocosm, in Upper Klamath Lake, Oregon from August 10 to August 13, 2018.

\section{Growth}

Between the tagging date (June 28, 2018) and the study termination dates (September 26-October 3, 2018; table 2), $\mathrm{CPT}$ and RPT fish grew slightly faster than control fish in the SARP pond. Control fish declined slightly in condition over the course of the study, while fish in the CPT and RPT mesocosms increased slightly in condition (fig. 8). Within the CPT and RPT mesocosms growth by length, but not weight, was positively associated with the probability of being Lost River suckers (fig. 8). Lost River sucker in the CPT and RPT mesocosms increased in length at an average $( \pm \mathrm{SD})$ rate of $0.65 \pm 0.11 \mathrm{~mm}$ SL per day and in weight at an average of $0.79 \pm 0.17$ grams (g) per day. SNS-KLS in the two mesocosms increased in length at an average rate of $0.52 \pm 0.07 \mathrm{~mm}$ SL and in weight at an average rate of $0.81 \pm 0.10 \mathrm{~g} /$ day. In contrast, both taxa in the SARP pond increased in length and weight at an average rate of $0.38 \pm 0.04 \mathrm{~mm} \mathrm{SL} /$ day and $0.27 \pm 0.08 \mathrm{~g} /$ day, respectively.

\section{Ichthyobodo Infection Intensity}

All fish sampled at the beginning of the study from both SARP and the KTFRF had Ichthyobodo sp. as detected in gill tissue by qPCR. Ichthyobodo sp. infection intensity ranged from 24 to 94 copies per $\mathrm{mg}$ of tissue in SARP fish and 12 to
35 copies of DNA per mg of tissue in the KTFRF fish. The only moribund fish sampled (collected from RPT on July 12) had the highest infection rate with 480 DNA copies per mg of tissue. Ichthyobodo sp. was not detected on the gills of the two fish that survived the study period at SWB or on any of the 10 fish sampled from CPT at the end of the study. Ichthyobodo sp. was detected on one fish sampled at the end of the study from the RPT mesocosm; that fish had an infection intensity of 54 copies of DNA per mg. The parasite was not detected on the other three fish sampled from this site. Ichthyobodo sp. was detected on two of five SARP fish at the end of the study. The infection intensity on these fish was 14 and 20 copies of DNA per mg of tissue.

\section{Histology}

Histological abnormalities in the liver were absent in preseason sampling and were mostly minor in fish sampled at all site locations at the end of the season (table 5). Perivascular and peribiliary cuffing, characterized by inflammatory cell infiltration around blood vessels and bile ducts, was observed in 40 percent of fish collected from the SARP pond and 30,20 , and 50 percent of fish sampled from CPT, RPT, and SWB mesocosms, respectively. The distribution and severity of cuffing ranged from focal and mild in fish sampled from SARP to focal or multifocal, and mild in fish sacrificed from 


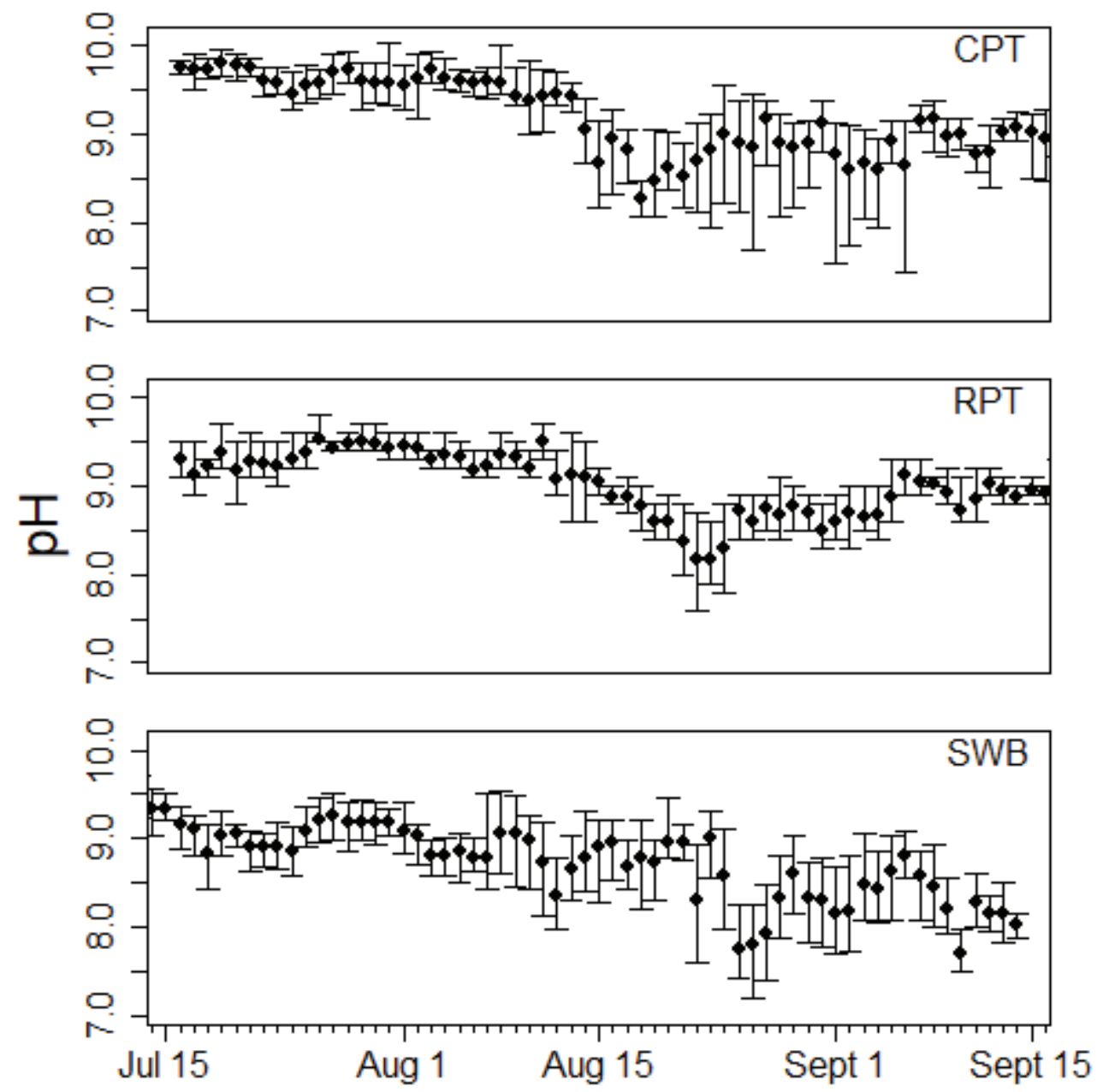

Figure 6. $\mathrm{pH}$ in the three mesocosms located at Cove Point (CPT), Rattlesnake Point (RPT), and Shoalwater Bay (SWB) in Upper Klamath Lake, Oregon, in 2018. Daily mean pH values are indicated by a dot and whiskers indicate daily minimum and maximum $\mathrm{pH}$.

the mesocosms. Focal and mild inflammation was present in the liver parenchyma of 40 percent of fish sampled from the SARP pond. Focal or multifocal, mild inflammation also occurred in the parenchyma of 30 and 50 percent of fish sacrificed from CPT and RPT, respectively. Inflammation of the liver parenchyma was multifocal and mild in both fish sacrificed from SWB.

Except for one of the two surviving SWB fish, all surviving fish examined from each site at the end of the season showed flocculent hepatocellular cytoplasmic vacuolization, which is characteristic of glycogen presence (table 5). Each of these fish also showed high hepatocyte glycogen levels (table 5). The single SWB fish showing no hepatocellular cytoplasmic vacuolization also had low hepatocellular glycogen levels. Vacuolization consistent with lipid storage was not observed in any fish.
Histological changes observed in the liver of the moribund fish sampled at SARP included focal, mild peribiliary/ perivascular cuffing, no vacuolization, and no hepatic glycogen. A large focus of red blood cells surrounded by autolyzed tissue (presumably liver) was also present in the liver of this fish.

Histological abnormalities in the hematopoietic kidney and spleen were only observed in apparently healthy fish collected from SARP (table 6). Focal, mild inflammation was present in the kidney and spleen of one fish sampled preseason. Kidney inflammation consisted primarily of lymphocyte infiltration into the tissue, whereas inflammation in the spleen was usually associated with pigmented macrophage aggregates. Multifocal, mild kidney inflammation was observed in another fish sacrificed from SARP at the end of the season. 


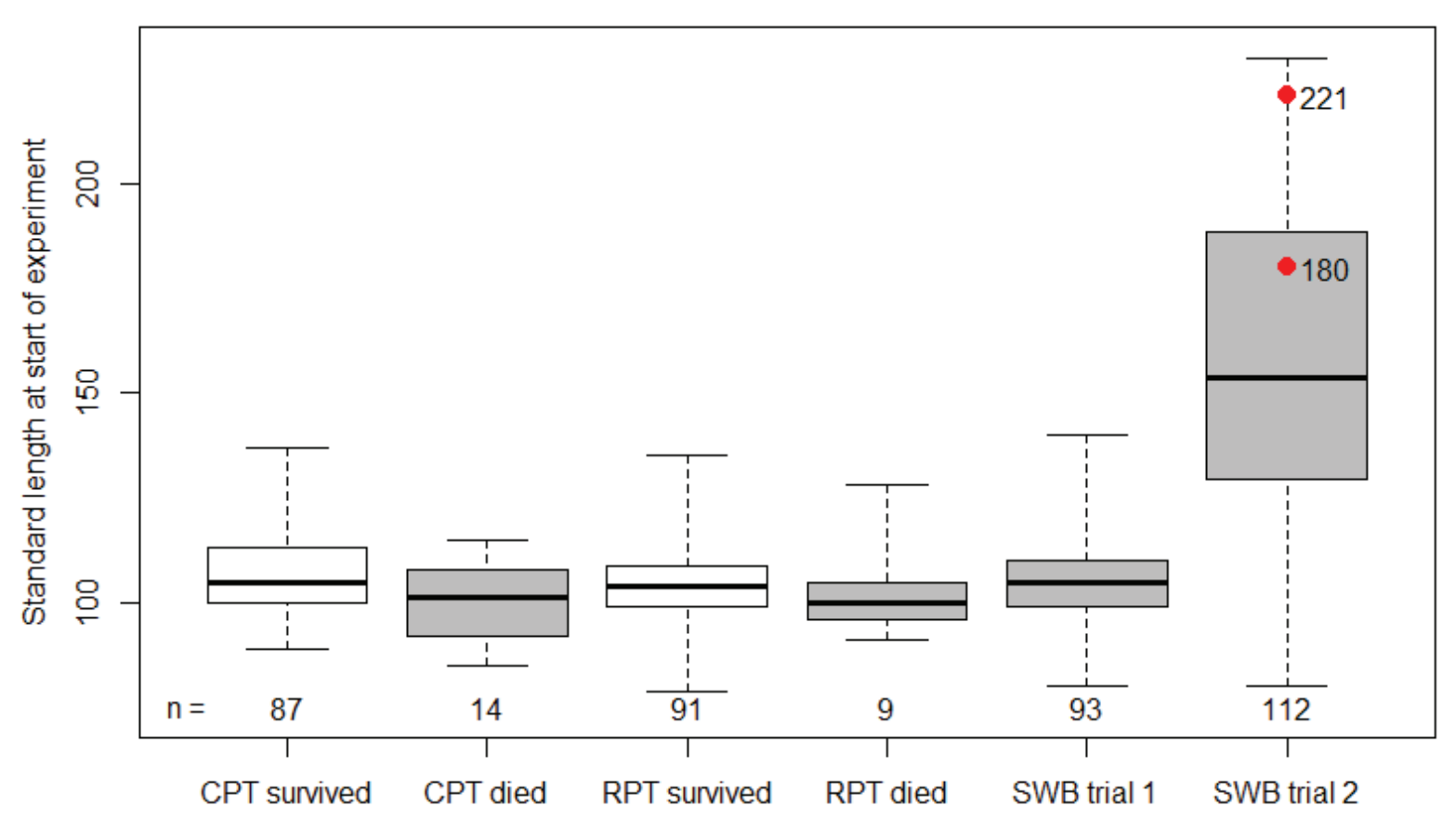

Figure 7. Standard lengths $(\mathrm{mm})$ of suckers at the time of tagging that survived or died in each of three mesocosms in Upper Klamath Lake, Oregon, in 2018. The location of the three mesocosm sites: Cove Point (CPT), Rattlesnake Point (RPT), and Shoalwater Bay (SWB), are shown in figure 1. White boxes show fish that survived. Grey boxes show fish that died. Red dots indicate lengths of the two fish that survived Trial 2 (July 26 start date) at SWB. All fish died in SWB Trial 1 (June 28 start date). Boxes indicate the 25th and 75th percentiles, lines show median values, and the whiskers indicate the maximum and minimum values.

Table 3. Numbers of tagged and untagged fish, deaths, recovered bodies, and surviving fish introduced to each mesocosm and the Sucker Assisted Rearing Program (SARP) control pond.

[Mesocosm locations are shown in figure 1 and are as follows: Cove Point (CPT), Rattlesnake Point (RPT) Shoalwater Bay (SWB). Two separate introductions of fish into the SWB are indicated by the dates fish were added to the mesocosm.]

\begin{tabular}{rrrrrr}
\hline & \multicolumn{5}{c}{ Site } \\
\cline { 2 - 6 } Category of Fish & CPT & RPT & $\begin{array}{c}\text { SWB } \\
\text { (July 9) }\end{array}$ & $\begin{array}{c}\text { SWB } \\
\text { (Aug. 6) }\end{array}$ & SARP Pond \\
\hline Tagged fish introduced to mesocosm or pond & 103 & 100 & 99 & 120 & 100 \\
Tags never detected in the mesocosm or pond & 3 & 5 & 1 & 2 & NA \\
Deaths determined by remote detection & 15 & 8 & 99 & 118 & NA \\
Dead tagged fish recovered & 14 & 8 & 96 & 115 & 0 \\
Dead untagged fish recovered & 0 & 0 & 2 & 2 & 0 \\
Untagged fish recovered alive at end of study & 4 & 4 & 0 & 0 & 0 \\
Tagged fish surviving until end of the study & 87 & 91 & 0 & 2 & 89 \\
Proportion all fish surviving & 0.86 & 0.90 & 0.00 & 0.02 & 0.89 \\
\hline
\end{tabular}


Table 4. Numbers of suckers that were identified to species, in a pond at the Sucker Assisted Rearing Program (SARP) rearing facility and in mesocosms at Cove Point (CPT) and Rattlesnake Point (RPT).

[The numbers of fish that died are shown in parentheses. Suckers were identified using 18 single nucleotide polymorphisms. LRS, Lost River Sucker; prob[LRS], probability of species assignment as LRS; SNS-KLS, Shortnose or Klamath largescale sucker]

\begin{tabular}{cccc}
\hline $\begin{array}{c}\text { Pond or } \\
\text { Mesocosm }\end{array}$ & LRS & $\begin{array}{c}\text { Intermediate } \\
\text { prob[LRS] }\end{array}$ & SNS-KLS \\
\hline SARP & $36(6)$ & $28(1)$ & $31(2)$ \\
CPT & $35(6)$ & $26(5)$ & $24(3)$ \\
RPT & $41(5)$ & $23(1)$ & $20(2)$ \\
\hline
\end{tabular}

No histopathological abnormalities were observed in any other tissues examined in fish collected during the preseason or end of season from any site. The only parasites observed were adult digeneans in the gastrointestinal tracts of 30 percent of fish sampled from CPT and 60 percent of fish from RPT at the end of the season. No host response was observed (data not shown).

\section{Discussion}

Extreme hypoxia is the most obvious explanation for the rapid mortality that occurred at SWB. On two occasions, nearly all suckers stopped moving within an hour of oxygen declining below 13.3 percent. Fewer suckers died at SWB on August 11 as oxygen saturation was both declining and less than about 30 percent saturation. Better survival of suckers in SWB on August 10 when oxygen saturation dipped below 10 percent may have resulted from unmeasured water column stratification that created refuge near the surface. At the same time on August 10 at the nearby MDN water-quality monitoring station, oxygen saturation was less than 10 percent $1 \mathrm{~m}$ off the bottom and supersaturated $1 \mathrm{~m}$ below the surface. If similar stratification occurred at SWB, our single sonde located at mid-water-column depth would not have detected it.

The slightly faster growth rates of both taxa of fish reared in CPT and RPT mesocosms, compared to the SARP pond, may have been due to differences in temperature fluctuations, minimum temperatures, food quantity or quality, or a combination of these factors. The apparent slight decrease in condition in SARP fish was caused by faster increasing length than weight compared to fish held in CPT and RPT and did not necessarily indicate a decrease in fish health. Diel variation in water temperatures within the SARP pond was about 2.5-3.0 ${ }^{\circ} \mathrm{C}$ and only about 1.0 to $1.5^{\circ} \mathrm{C}$ at CPT and RPT. Greater diel fluctuations in water temperature around a similar mean temperature can result in slower growth of fish (Hokanson and others, 1977). Suckers in the mesocosms likely consumed a combination of invertebrates off the net and from the benthos whereas suckers in SARP ponds likely consumed naturally produced prey from the bottom of the earthen ponds and Otohime S2 food.

Histology indicated that suckers were healthy and there were no significant differences in tissue condition among suckers held at SARP or in the mesocosms. Autolyzed tissues in the liver of one fish and kidney of another fish were likely a result of poor fixation or tissue damage during sampling and were not an indication of fish health. Parasites found in CPT and RPT suckers were likely not a problem for the fish because they were not associated with host response or reduced glycogen storage. The minor increase in liver inflammation between preseason and post season fish at CPT, RPT, and SARP may be a natural process. Similar inflammation was noted for wild-caught and mesocosm-held suckers collected from Clear Lake and Upper Klamath Lake in 2014 and 2016 (Burdick and others, 2017; Hereford and others, 2019).

The differences in Ichthyobodo sp. prevalence and intensity between the beginning and end of our study may relate to temperature differences. Ichthyobodo sp. intensities increase with temperatures above $22^{\circ} \mathrm{C}$ (Martin and others, 2021). Temperatures at the rearing facilities, when preseason samples were taken, averaged about $22^{\circ} \mathrm{C}$ at SARP and $18-19{ }^{\circ} \mathrm{C}$ at KTFRF. When fish were sampled at the end of the study, temperatures were about $16^{\circ} \mathrm{C}$ in the mesocosms and about 18-19 ${ }^{\circ} \mathrm{C}$ at the SARP facility. The greatest load of Ichthyobodo sp. on a fish in our study was found on a moribund fish collected from RPT on August 10 when water temperatures averaged around $22{ }^{\circ} \mathrm{C}$. The parasite load in this fish was lower than that observed to be associated with mortality of Lost River suckers in a laboratory study (Martin and others, 2021). Ichthyobodo sp. also were not observed by histological examination of gill tissue, indicating the parasite was not a primary factor leading to morbidity of this fish. While it appears that most fish had shed Ichthyobodo sp. infections by the time of the final sampling, it is unclear how prolific the parasite was during the middle of the study or how much this parasite contributed to mortality.

Although it appears that survival is very low for age- 0 suckers and high in most years for adult suckers in Upper Klamath Lake (Burdick and Martin, 2017; Hewitt and others, 2018), the relationship between size and survival of older juvenile suckers is unclear. At the beginning of our study, the age-1 SARP reared suckers averaged ( \pm standard error [SE]) $106.2 \pm 10.7 \mathrm{~mm}$ SL, whereas wild age-0 suckers in Upper Klamath Lake are typically $38-83 \mathrm{~mm}$ SL from July to September (Burdick and Martin, 2017). The 101-day summer survival proportion of age-1 Lost River suckers averaging ( \pm SE) $81.9 \pm 7.4 \mathrm{~mm} \mathrm{SL}$ in a mesocosm at RPT in 2017 was 0.35 (Burdick and others, 2020a). The 109-d summer survival of age-1 Lost River suckers averaging $( \pm \mathrm{SE}) 102.9 \pm 8.7 \mathrm{~mm} \mathrm{SL}$ in a mesocosm at RPT in 2016 was 0.88 (Hereford and others, 2019). In this study, the 80-day summer survival of suckers from a combination of sucker taxa was 0.90 . While survival was higher in the two years when larger fish were used, the effects of taxa, pre-study rearing practices, and interannual 


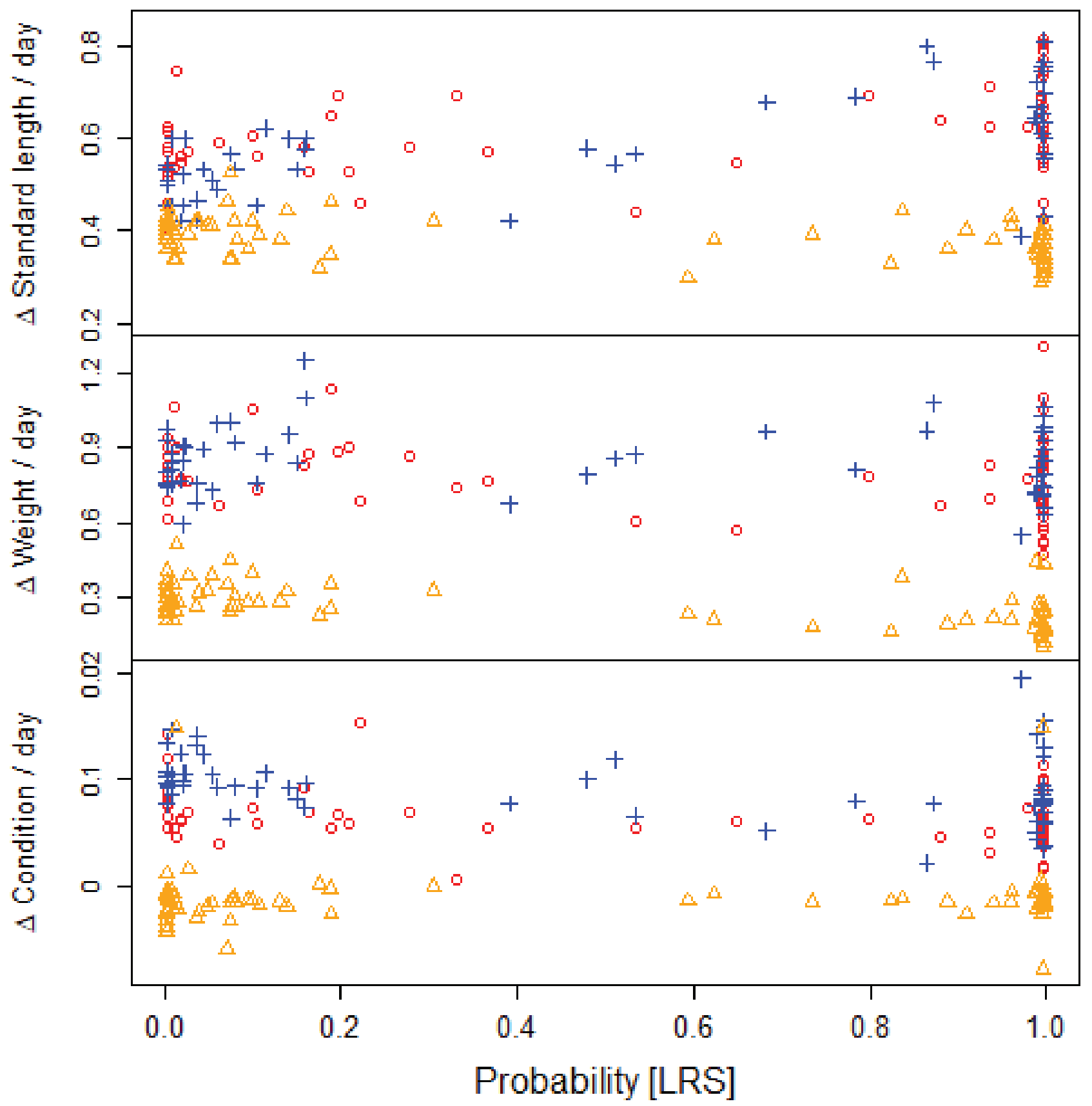

Figure 8. Daily change in length (millimeter standard length), weight (grams), and condition (micrograms per cubic millimeter) for SARP-reared suckers maintained in mesocosms at Rattlesnake Point (red), Cove Point (blue), and in a pond at the SARP rearing facility (orange triangles), plotted against the probability of being a Lost River sucker (Probability [LRS]). Probability [LRS] was calculated based on 18 single nucleotide polymorphisms. Low Probability [LRS] indicates a fish was more likely to be a Shortnose or Klamath largescale sucker, and a high Probability [LRS] indicates a fish was more likely to be a Lost River sucker. 


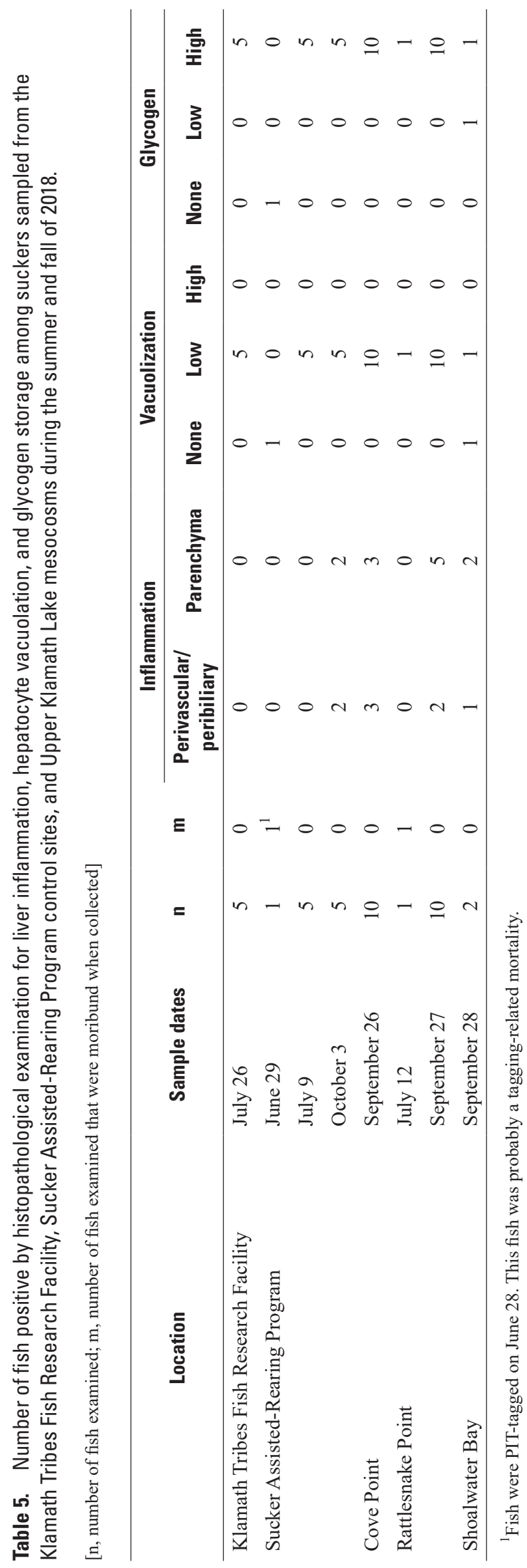


Table 6. Number of fish positive by histopathological examination for inflammation of the kidney and spleen among suckers sampled from the Klamath Tribes Fish Research Facility, Sucker Assisted-Rearing Program control sites, and Upper Klamath Lake mesocosms during the summer and fall of 2018.

[n, number of fish examined; $m$, number of fish examined that were moribund when collected]

\begin{tabular}{llcccc}
\hline \multicolumn{1}{c}{ Location } & \multicolumn{1}{c}{ Sample dates } & n & m & $\begin{array}{c}\text { Kidney } \\
\text { inflammation }\end{array}$ & $\begin{array}{c}\text { Spleen } \\
\text { inflammation }\end{array}$ \\
\hline Klamath Tribes Fish Research Facility & July 26 & 5 & 0 & 0 & 0 \\
Sucker Assisted-Rearing Program & June 29 & 1 & ${ }^{1} 1$ & 0 & 0 \\
& July 9 & 5 & 0 & 1 & 1 \\
Cove Point & October 3 & 5 & 0 & 1 & 0 \\
Rattlesnake Point & September 26 & 10 & 0 & 0 & 0 \\
& July 12 & 1 & 1 & 0 & 0 \\
Shoalwater Bay & September 27 & 10 & 0 & 20 & 0 \\
\hline
\end{tabular}

${ }^{1}$ Fish were PIT-tagged on June 28 . This fish was probably a tagging-related mortality.

${ }^{2}$ One kidney was severely autolyzed and no results were recorded.

differences in conditions, including water quality, cannot be ruled out as primary or contributing factors affecting sucker survival. Nevertheless, larger juvenile fish can have greater glycogen stores that may allow them to survive other stressors better than smaller fish of the same species (Nilsson and Östlund-Nilsson, 2008).

This study was conducted to compare three in-lake locations and a SARP pond for releasing suckers, rearing suckers, or both. In the single year that our study was conducted, SWB was found to be an unsuitable location to rear suckers. The mesocosms at RPT and CPT provided similar survival and slightly better growth than the SARP pond in 2018. These results only reflect the year in which this study was conducted and may not be true in other years. Two net pens located at RPT were stocked with 534 age-1 suckers averaging about 136 $\mathrm{mm} \mathrm{SL} \mathrm{(160} \mathrm{mm} \mathrm{TL)} \mathrm{and} 480$ age-2 suckers averaging about $204 \mathrm{~mm}$ SL ( $237 \mathrm{~mm}$ TL) by the USFWS on June 25 and 26, 2019 (Zachary Tiemann, oral commun., 2019, USFWS). These fish were from the same source as the fish used in our study and were of a mixed species composition. All but 10 of the age- 2 fish in these net pens died prior to being harvested on October 16, 2019. The cause of death for these fish is unknown and poor water quality did not explain the death in the USFWS net pens (USGS, 2020). The primary causes of juvenile sucker mortality, best practices for in-lake rearing, and best locations for releasing SARP suckers in Upper Klamath Lake are still unknown.

\section{Acknowledgments}

Data collection and project implementation were made possible with the help of the U.S. Geological Survey (USGS) Klamath Falls Field Station staff including, Ross Clyma, Joshua Hargrove, Brian Hayes, Justin Howard, Todd Perry, David Smith, and Stephen Staiger. Danielle Hereford (Bureau of Reclamation) consulted on the project design. Barbara Martin (USGS), the Klamath Tribes, and the U.S. Fish and Wildlife Service cared for captive suckers used in this project. Caylen Kelsey and Alta Harris (USGS) provided database support. Scott Foott and Ron Stone (U.S. Fish and Wildlife Service) propagated and raised some of the Lost River suckers used in this project. Maureen Purcell and Rachel Powers of the USGS completed the genetic assay for Ichthyobodo sp. Marshal Hoy (USGS) completed the genetic identification of suckers. The Nature Conservancy and the Bureau of Reclamation provided winter storage for the docks.

\section{References Cited}

Anderson, G.O., Wilkens, A.X., Burdick, S.M., and VanderKooi, S.P., 2009, Seasonal distribution and abundance of larval and juvenile Lost River and Shortnose suckers in Hanks Marsh, Upper Klamath National Wildlife Refuge, Upper Klamath Lake, Oregon—2007 Annual Report: U.S. Geological Survey Open File Report 2009-1014, 36 p. [Also available at https://doi.org/10.3133/ ofr20091014]. 
Benson, B.B., and Krause, D., Jr., 1980, The concentration and isotopic fractionation of gases dissolved in freshwater equilibrium with atmosphere-1, Oxygen: Limnology and Oceanography, v. 25, no. 4, p. 662-671. [Also available at https://doi.org/10.4319/1o.1980.25.4.0662].

Benson, B.B., and Krause, D., Jr., 1984, The concentration and isotopic fractionation of oxygen dissolved in freshwater and seawater in equilibrium with the atmosphere: Limnology and Oceanography, v. 29, no. 3, p. 620-632. [Also available at https://doi.org/10.4319/1o.1984.29.3.0620].

Bortleson, G.C., and Fretwell, M.O., 1993, A review of possible causes of nutrient enrichment and decline of endangered sucker populations in Upper Klamath Lake, Oregon: U.S. Geological Survey Water-Resources Investigations Report 1993-4087, 32 p.

Burdick, S.M., 2011, Tag loss and short-term mortality associated with passive integrated transponder tagging of juvenile Lost River suckers: North American Journal of Fisheries Management, v. 31, no. 6, p. 1088-1092. [Also available at https://doi.org/10.1080/02755947.2011.641067].

Burdick, S.M., Conway, C.M., Elliott, D.G., Hoy, M.S., Dolan-Caret, A., and Ostberg, C.O., 2017, Health and condition of endangered young-of-the-year Lost River and shortnose suckers relative to water quality in Upper Klamath Lake, Oregon, 2014-2015: U.S. Geological Survey Open-File Report 2017-1134, 40 p. [Also available at https://doi.org/10.3133/ofr20171134].

Burdick, S.M., and Martin, B.A., 2017, Inter-annual variability in apparent relative production, survival, and growth of juvenile Lost River and shortnose suckers in Upper Klamath Lake, Oregon, 2001-15: U.S. Geological Survey Open-File Report 2017-1069, 55 p. [Also available at https://doi.org/ 10.3133/ofr20171069].

Burdick, S.M., Hereford, D.M., Conway, C.M., Banet, N.V., Powers, R., Martin, B.A., and Elliott, D.G., 2020a, Mortality of endangered juvenile lost river suckers associated with cyanobacteria blooms in mesocosms in Upper Klamath Lake, Oregon: Transactions of the American Fisheries Society, v. 149, no. 3, p. 245-265. [Also available at https://doi.org/10.1002/tafs.10227].

Burdick, S.M., Hewitt, D.A., Martin, B.A., Schank, L., and Rounds, S., 2020b, Effects of harmful algal blooms and associated water quality on endangered lost river and shortnose suckers: Harmful Algae, v. 97, p. 101847. [Also available at https://doi.org/10.1016/j.hal.2020.101847].

Carson, F.L., 1997, Histotechnology-A self-instructional text 2nd ed.: Chicago, ASCP Press, 304 p.
Cooperman, M.S., and Markle, D.F., 2004, Abundance, size, and feeding success, of larval shortnose sucker and Lost River suckers from different habitats in the littoral zone of Upper Klamath Lake, Oregon: Environmental Biology of Fishes, v. 71, no. 4, p. 365-377, https://doi.org/10.1007/ s10641-004-4181-x.

Day, J., Jacobs, J.L., and Rasmussen, J., 2017, Considerations for the propagation and conservation of endangered lake suckers of the Western United States: Journal of Fish and Wildlife Management, v. 8, no. 1, p. 301-312. [Also available at https://doi.org/10.3996/022016-JFWM-011].

Eldridge, D.B., Caldwell Eldridge, S.L.C., Schenk, L.N., Tanner, D.Q., and Wood, T.M., 2012, Water-quality data from Upper Klamath and Agency Lakes, Oregon, 2009-10: U.S. Geological Survey Open-File Report 2012-1142, 32 p. [Also available at https://doi.org/10.3133/ofr20121142].

Hereford, D.M., Conway, C.M., Burdick, S.M., Elliott, D.G., Perry, T.M., Dolan-Caret, A., and Harris, A.C., 2019, Assessing causes of mortality for endangered juvenile Lost River suckers (Deltistes luxatus) in mesocosms in Upper Klamath Lake, south-central Oregon, 2016: U.S. Geological Survey Open -File Report 2019-1006, 88 p.

Hewitt, D.A., Janney, E.C., Hayes, B.S., and Harris, A.C., 2018, Status and trends of adult Lost River (Deltistes luxatus) and shortnose (Chasmistes brevirostris) sucker populations in Upper Klamath Lake, Oregon, 2017: U.S. Geological Survey Open-File Report 2018-1064, 31 p. [Also available at https://doi.org/10.3133/ofr20181064].

Hokanson, K.E.F., Kleiner, C.F., and Thorslund, T.W., 1977, Effects of constant temperatures and diel temperature fluctuations on specific growth and mortality rates and yield of juvenile rainbow trout Salmo gairdneri: Journal of the Fisheries Research Board of Canada, v. 34, no. 5, p. 639-648. [Also available at https://doi.org/10.1139/ f77-100].

Hoy, M.S., and Ostberg, C.O., 2015, Development of 20 TaqMan assays differentiating the endangered shortnose and Lost River suckers: Conservation Genetics Resources, v. 7, no. 3, p. 673-676. [Also available at https://doi.org/ 10.1007/s12686-015-0474-y].

Isaksen, T.E., Karlsbakk, E., Repstad, O., and Nylund, A., 2012, Molecular tools for the detection and identification of Ichthyobodo spp. (Kinetoplastida), important fish parasites: Parasitology International, v. 61, no. 4, p. 675-683. [Also available at https://doi.org/10.1016/j.parint.2012.07.006].

Lease, H.M., Hansen, J.A., Bergman, H.L., and Meyer, J.S., 2003, Structural changes in gills of Lost River Suckers exposed to elevated $\mathrm{pH}$ and ammonia concentrations: Comparative Biochemistry and Physiology, v. 134, p. 491-500. 
Martin, B.A., Burdick, S.M., Purcell, M.K., and Powers, R.L., 2021, Effects of Temperature on Survival of Lost River Suckers with a Natural Infection of Ichthyobodo spp.: North American Journal of Aquaculture, 8 p., https://doi. org/10.1002/naaq.10186.

Meyer, J.S., and Hansen, J.A., 2002, Subchronic toxicity of low dissolved oxygen concentrations, elevated $\mathrm{pH}$, and elevated ammonia concentrations to Lost River suckers: Transactions of the American Fisheries Society, v. 131, no. 4, p. 656-666. [Also available at https://doi.org/10.1577/ 1548-8659(2002)131<0656:STOLDO>2.0.CO;2].

National Research Council (NRC), 2004, Endangered and threatened fishes in the Klamath River Basin-Causes of decline and strategies for recovery: Washington, D.C., The National Academies Press, 395 p.

Nilsson, G.E., and Östlund-Nilsson, S., 2008, Does size matter for hypoxia tolerance in fish?: Biological Reviews of the Cambridge Philosophical Society, v. 83, no. 2, p. 173-189. [Also available at https://doi.org/10.1111/ j.1469-185X.2008.00038.x].

Ricker, W.E., 1975, Computation and interpretation of biological statistics of fish populations: Bulletin of the Fisheries Research Board of Canada 191, 382 p.
Rounds, S., 2011, Analysis to support the replacement of Weiss (1970) equations by Benson and Krause $(1980,1984)$ equations for USGS computation of solubility of dissolvedoxygen in water: U.S. Geological Survey Technical Memorandum 2011.03, $13 \mathrm{p}$.

Saiki, M.K., Monda, D.P., and Bellerud, B.L., 1999, Lethal levels of selected water quality variables to larval and juvenile Lost River and shortnose suckers: Environmental Pollution, v. 105, no. 1, p. 37-44. [Also available at https://doi.org/10.1016/S0269-7491(98)00212-7].

U.S. Fish and Wildlife Service and National Marine Fisheries Service (USFWS and NMFS), 2019, Biological Opinion on the Effects of Proposed Klamath Project Operations from April 1, 2019, through March 31, 2024, on the Lost River Sucker and the Shortnose Sucker: 222 p., https://kbifrm. psmfc.org/wp-content/uploads/2019/04/FWS_2019 0503_BiOp-Klamath-Project-Operation-VI508.pdf.

U.S. Geological Survey (USGS), 2020, Data inventory page for site 11505900 - Upper Klamath Lake at Rattelsnake Point, Oregon: U.S. Geological Survey, webpage accessed July, 2020 at https://waterdata.usgs.gov/nwis/dv/?site_no= 11505900\&agency_cd=USGS\&amp;referred_module=qw.

Wagner, R.J., Mattraw, H.C., Ritz, G.F., and Smith, B.A., 2000, Guidelines and standard procedures for continuous water-quality monitors: site selection, field operation, calibration, record computation, and reporting: U.S. Geological Survey Water-Resources Investigation Report 2000-4252, 27 p. 
Publishing support provided by the U.S. Geological Survey Science Publishing Network, Tacoma Publishing Service Center

For more information concerning the research in this report, contact the

Director, Western Fisheries Research Center

U.S. Geological Survey

6505 NE 65th Street

Seattle, Washington 98115-5016

https://www.usgs.gov/centers/wfrc 


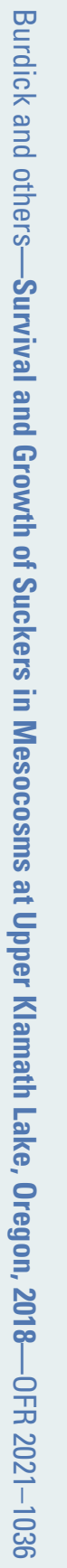

